\title{
Vacancies, employment growth and the demand for newcomers on the labour market
}

Citation for published version (APA):

de Grip, A., Meijboom, P., \& Willems, E. J. T. A. (1993). Vacancies, employment growth and the demand for newcomers on the labour market. Researchcentrum voor Onderwijs en Arbeidsmarkt, Faculteit der Economische Wetenschappen. ROA Research Memoranda No. $1 \mathrm{E}$ https://doi.org/10.26481/umaror.199301E

Document status and date:

Published: 01/01/1993

DOI:

10.26481/umaror.199301E

Document Version:

Publisher's PDF, also known as Version of record

\section{Please check the document version of this publication:}

- A submitted manuscript is the version of the article upon submission and before peer-review. There can be important differences between the submitted version and the official published version of record.

People interested in the research are advised to contact the author for the final version of the publication, or visit the DOI to the publisher's website.

- The final author version and the galley proof are versions of the publication after peer review.

- The final published version features the final layout of the paper including the volume, issue and page numbers.

Link to publication

\footnotetext{
General rights Owners
rights.

- You may freely distribute the URL identifying the publication in the public portal. please follow below link for the End User Agreement:

www.umlib.nl/taverne-license

Take down policy

If you believe that this document breaches copyright please contact us at:

repository@maastrichtuniversity.nl

providing details and we will investigate your claim.
}

Copyright and moral rights for the publications made accessible in the public portal are retained by the authors and/or other copyright owners and it is a condition of accessing publications that users recognise and abide by the legal requirements associated with these

- Users may download and print one copy of any publication from the public portal for the purpose of private study or research.

- You may not further distribute the material or use it for any profit-making activity or commercial gain

If the publication is distributed under the terms of Article $25 \mathrm{fa}$ of the Dutch Copyright Act, indicated by the "Taverne" license above, 


\section{VACANCIES, EMPLOYMENT GROWTH \\ AND THE DEMAND FOR NEWCOMERS \\ ON THE LABOUR MARKET}

ROA-RM-1993/1E

Andries De Grip, Petra Meijboom, Ed Willems

Paper presented at the workshop 'Measurement and Analysis of Vacancies: An International Comparison', University of Limburg, Maastricht, 28th-29th January, 1993.

RESEARCH CENTRE FOR EDUCATION AND THE LABOUR MARKET

Faculty of Economics and Business Administration

Rijksuniversiteit Limburg

Maastricht, April 1993 


\section{CIP-GEGEVENS KONINKLIJKE BIBLIOTHEEK, DEN HAAG}

\section{Grip, Andries de}

Vacancies, employment growth and the demand for newcomers on the labour market/Andries de Grip, Petra Meijboom, Ed Willems. - Maastricht: Research Centre for Education and Labour Market, Faculty of Economics and Business Administration, Rijksuniversiteit Limburg. - (ROARM-1993/1E)

Met lit. opg.

ISBN 90-5321-099-7 in spiraalband

Trefw.: arbeidsmarkt 
CONTENTS

ABSTRACT

1. INTRODUCTION

2. THE RELEVANCE OF VACANCY STATISTICS

3. FLUCTUATIONS IN VACANCIES AND EMPLOYMENT GROWTH

4. VACANCIES, EMPLOYMENT GROWTH, AND REPLACEMENT DEMAND

5. CONCLUSIONS 


\begin{abstract}
This paper focuses on the relevance of vacancy data and employment growth rates as indicators of the demand for newcomers on the labour market. It begins with an illustration of the relation between vacancies and employment growth. Then we discuss the relevance of the three components of the total number of vacancies: new jobs, replacement demand and job-tojob mobility. Most analyses refer to economic sectors. Information is also given on the share of employment growth in the total number of job openings for newcomers, differentiated by occupational class and level of education.
\end{abstract}




\section{INTRODUCTION}

In the last few years the analysis of vacancy statistics has received relatively much attention in the economic literature. In several countries vacancy figures are used to describe the frictions on the labour market. Apart from the 'traditional' UV-analysis (see e.g. Holt, 1970, Kuipers and Buddenberg, 1978, and Budd, Levine and Smith, 1987) research has focused on the problem of vacancies that are hard to fill and the average vacancy duration (see e.g. Van Ours, 1987 and 1989). In itself this interest of empirical labour economists is understandable: reliable vacancy data can be seen as an indicator of the labour market situation, both as an indication of excess demand and as a general indicator of the labour market situation and, in combination with unemployment data, as an indicator of labour market matching problems.

However, as the Organisation for Economic Co-operation and Development (OECD) has stated, vacancy data is "a good barometer of cyclical changes in the labour market, [although] its performance as an indicator of changes in the overall economic situation was considered less good" (OECD, 1992, p. 28). Moreover, in describing the situation of actors on either the demand or supply side of the labour market, vacancy statistics are not adequate. Especially for newcomers on the labour market, the number of vacancies is an inadequate indicator of the number of job openings (De Grip, Heijke, and Dekker, 1989). ${ }^{1}$ Because of the job mobility of workers, the number of vacancies is greater than the number of job openings for newcomers. Therefore it is important to determine the various components of the vacancy flows separately. A distinction can be made between the job openings due to employment growth, replacement demand, and job-to-job mobility.

In occupational and vocational counselling employment growth is often also used as an indicator of the labour market prospects of newcomers on the labour market. However, as we will argue in this paper, the number of job openings for newcomers is not merely determined by employment growth, since replacement demand is also an important cause of job openings for newcomers.

In this paper, we will discuss the relevance of vacancy data and employment growth rates as indications of the demand for newcomers on the labour market in both a conceptual and empirical sense. We will ask what proportion of the total number of vacancies is on balance open for newcomers and whether this fraction is constant over time. Moreover, the relative importance of the two elements of the total demand for newcomers, employment growth and replacement demand, will be analyzed.

The structure of the remainder of this paper is as follows. Section 2 deals with the relevance of vacancy statistics. In this section we describe the components of the total number of vacancies and make some remarks on the measurement of vacancy data and replacement demand. The section ends with the presentation of some ratios that will be used in the paper to describe

1. Van der Velden and Willems (1992) use a broader concept of 'labour market position'. In addition to vacancy and unemployment data, they take into account forecasts of the future situation on the labour market, the relative dependency on school-leavers, the underutilization of workers, the opportunities for occupational mobility etc.. 
$-2-$

- explicitly or implicitly - the relation between total vacancies and its three components. Section 3 compares the extent to which employment growth rates and vacancy rates reflect business cycle fluctuations. Section 4 reports on the various components of the number of vacancies: employment growth, replacement demand and job-to-job mobility. Unfortunately, most analyses refer only to economic sectors, because there is no adequate vacancy data on occupational classes and types of education. For the same reason the various analyses can not refer to the same period of analysis. Finally section 5 gives some principal conclusions. 


\section{THE RELEVANCE OF VACANCY STATISTICS}

Components of the total number of vacancies

As was said in the introduction, the total number of vacancies consists of three components (see equation (1)):

$V=\max (\Delta E, 0)+R D+M$

where:

$V \quad=$ vacancies (flow data);

$\Delta E=$ employment growth;

$R D$ = replacement demand;

$M \quad$ = job-to-job mobility.

Vacancies as a consequence of employment growth, which will be called 'expansion demand' (see e.g. Beekman, Dekker, De Grip, and Heijke, 1991), are the first component. The second is the vacancies due to replacement demand, resulting from the departure of employees from the workforce or from the economic sector or occupational class in question. Willems and De Grip (1993) define replacement demand as: "the jobs resulting from the departures of workers that have to be filled by new workers. For example, replacement demand can be a result of permanent departures from the labour force, due to retirement, (temporary) withdrawals of women due to birth and child-rearing, occupational mobility etc.". It is important to note that lay-offs will only result in replacement demand if a new employee is hired. So replacement demand is measured as the lowest of the number leaving the category under consideration (the outflow) and the number taking up positions (the inflow). Algebraically (compare Schettkat, 1992):

$\begin{array}{ll}R D=I & \text { if } I<0 \\ R D=O & \text { if } I \geq 0\end{array}$

where:

$I \quad=$ inflow of workers;

$O=$ outflow of workers.

The dimension in which replacement demand is measured is a significant factor in the definition of replacement demand. If we consider the replacement demand by economic sector, workers changing to another sector are recorded as replacement demand. But intra-sectoral mobility does not result in job openings for the economic sector in question and will therefore not lead to replacement demand. So we can rewrite equation (1) as follows:

$V=\max (\Delta E, 0)+R D_{1}+R D_{2}+M_{1}$

where:

$R D_{1}=$ replacement demand caused by departures out of the work force; 
$R D_{2}=$ replacement demand caused by inter-sectoral mobility;

$M_{1}$ = intra-sectoral job-to-job mobility.

An analogous situation holds for the replacement demand by occupational class, where interoccupational mobility affects replacement demand. However, the replacement demand by type of education will generally refer only to the vacancies due to the departure of workers from the work force $\left(R D_{1}\right)$, assuming that the skill profile of the workers does not change significantly during their working careers.

Finally, the last element on the right-hand side of equations (1) and (3) represents the intrasectoral (or intra-occupational) job-to-job mobility. In his dissertation, Van Ophem (1989) makes a distinction between seven different types of mobility. Moreover, he distinguishes within each of these types a voluntary and a non-voluntary component. Some types of mobility overlap elements of the concept of replacement demand described above. However, we refer here to job-to-job mobility in a more restricted sense as job mobility in which the economic sector or the occupational class, as applicable, does not change.

In figure 1 the various components of the number of vacancies are represented graphically. In the upper part of the diagram the various elements of replacement demand are given. Together with the employment growth, this gives the total demand for newcomers on the labour market. Adding the job-to-job mobility within the economic sectors will give the number of vacancies.

For newcomers on the labour market (school-leavers and young short-term unemployed people) the total number of vacancies is not relevant, as the vacant jobs that are filled by persons who switch from one job to another can, on balance, not be considered as job openings for newcomers on the labour market. After all, if a vacancy is filled by an employed person, a second vacancy arises due only to the fact that someone who already had a job has filled the first vacancy. For newcomers there is, on balance, only one job opening. Therefore only two of the three components of total vacancies that were mentioned above - expansion demand and replacement demand - are indicators of the labour demand for newcomers.

With regard to expansion demand, we can distinguish two possible positions, (1) employment growth, and (2) decreasing or steady employment. If the employment level is stable or declining, the total demand for newcomers on the labour market will refer only to replacement demand. Then the total number of vacancies equals the sum of replacement demand and job-tojob mobility. However, decreasing or constant employment will most probably occur in a recession, when job-to-job mobility will be restricted to relatively few workers. Furthermore, in a recession period, there will probably be 'labour queues' within firms (labour hoarding), so the number of vacancies will be relatively low. These two elements mean that in a recession period a relatively large part of the total number of vacancies is available for fresh labour supply. On the other hand, if employment increases in an economic upswing, job-to-job mobility will probably be relatively high, as mobility chains both within firms and in the external market will then inflate the total number of vacancies. Moreover, in that situation the internal labour 
$-5-$

reserves within firms will probably be low. In that situation the total demand for newcomers on the labour market will presumably make up a relatively small proportion of all vacancies.

Figure 1. Elements of the total number of vacancies

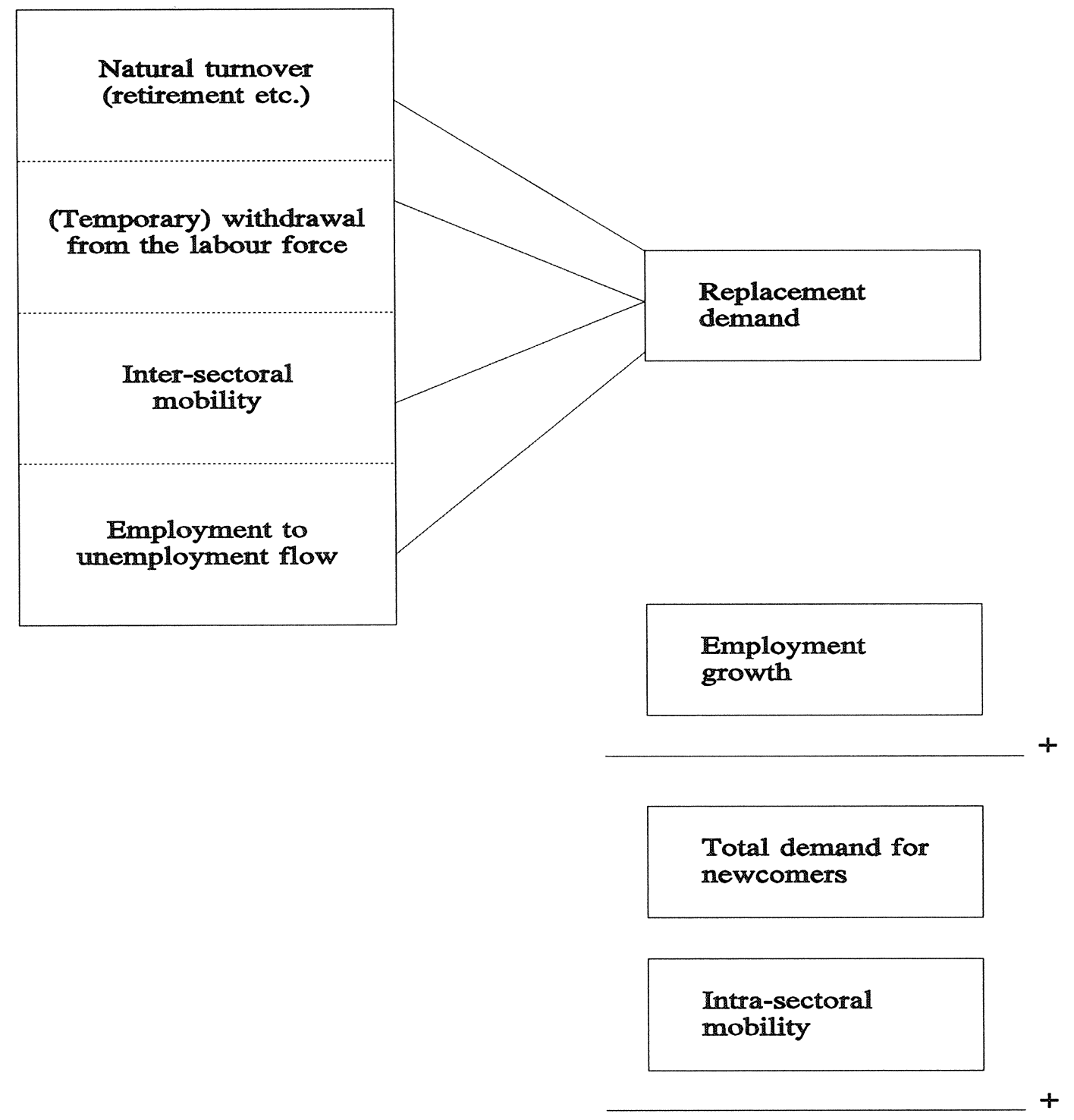

Total number of vacancies 
So far, we have implicitly assumed that every job that becomes vacant is measured in the vacancy statistics. This is definitely not true for vacancy data based on the records of the Employment Services (see for example Van der Bij, 1992 or Allaart, Praat, and Vosse, 1992). However, it is also doubtful whether vacancy data based on a survey of employers, records all vacancies. For example, vacancies that are immediately filled - by means of persons from a pool of applicants (the internal or external 'labour queue') - will usually not be reported in a survey, although firms are reminded that such vacancies should be included in the vacancy survey of the Dutch Central Bureau of Statistics (CBS) (Van Bastelaer and Laan, 1993). It is also doubtful whether all the vacancies are reported where the departure of one employee leads to a chain of vacancies on the firm's internal labour market (see also Schettkat, 1992; compare Schwan and Soeters, 1990). ${ }^{2}$

The measurement of replacement demand is also not perfect. Theoretically, the best way of measuring replacement demand is by means of data on the flows into and out of the labour market. Unfortunately this kind of flow data is not available for the Netherlands. So by means of the 'cohort components' method we calculate cohort-change rates as given in equation (4):

$$
{ }_{k} \dot{W}_{s, a}^{t, n}=\sqrt[n]{\frac{k W_{s, a+n}^{t}}{{ }_{k} W_{s, a}^{t-n}}}-1
$$

where:

$$
\begin{aligned}
{ }_{k} \dot{W}_{s, a}^{t, n}= & \text { average annual net inflow or outflow ratio of workers in economic sector s of age } \\
& \text { group a (with class width } k \text { ) at time } t-n \text { during the period }(t-n, t) ; \\
{ }_{k} W_{s, a}^{t}= & \text { number of workers in economic sector } s \text { of age group a (with class width } k \text { ) at time } t .
\end{aligned}
$$

These rates are based on the number of persons of the same birth cohort who were employed at two different times (see Shryock and Siegel, 1980). If the left-hand side of equation (4) is greater than zero, there is a net outflow of workers of a certain age group. If it is less than zero there is a net inflow.

Using this method, we only measure 'net' inflows or outflows, rather than the real 'gross' flows on the labour market. This means that replacement demand satisfied by re-entering workers is not adequately measured. However, to establish the demand for newcomers on the labour market, this restriction to 'net' flows is desirable (see De Grip and Willems, 1992). Moreover, by splitting up the stock data by age and gender, we can obtain a reasonable approximation of the relevant labour market flows, although a certain amount of under-measurement is not excluded (for more details see Willems and De Grip, 1993).

2. This under-measurement problem in relation to quickly-filled vacancies would suggest that the proportion of vacancies which are hard to fill is overestimated, so that it is not a reliable measure of labour market tensions. 


\section{Some ratios}

On the basis of this reasoning we can derive some ratios with regard to vacancies, expansion demand (employment growth) and replacement demand. An often used and simple indicator of labour market tensions is the vacancy rate, defined as:

$R_{1}=\frac{V^{*}}{E}$

where:

$\boldsymbol{R}_{1} \quad$ = vacancy rate;

$V^{*}=$ vacancies (stock data);

$E \quad=$ employment level.

This vacancy rate index indicates labour market 'bottlenecks', in the sense of excess demand. In a tight labour market the number of unfilled vacancies, and therefore $R_{1}$, will be high. If there is a supply excess, the index will be relatively low, its value representing friction or matching problems.

A second ratio describes the relative importance of 'net' employment growth ${ }^{3}$ for the total number of vacancies:

$R_{2}=\frac{\max (\Delta E, 0)}{V}$

where:

$R_{\mathbf{2}} \quad=$ ratio employment growth/vacancies.

If we derive this ratio over time, $R_{\mathbf{2}}$ indicates the relative fluctuation of vacancies in relation to the expansion demand. The ratio is equal to zero if employment is stable or declining. In a period of economic upswing both $\Delta E$ and $V$ will increase. As the number of new vacancies will in general be much higher than the expansion demand - because of the increasing job-to-job mobility - the index will probably be smaller than in a recession. However, if the employment change is greater than the increase in job mobility, ${ }^{4}$ the index will be greater in an upswing period.

For the central problem of this paper, the relevance of vacancy data in assessing the total demand for newcomers on the labour market, the following ratio is of crucial importance:

3. We use the word 'net' here, because no non-aggregated data on the various labour inflows at firm level are available. Therefore, we have to use data on the total employment mutations within an economic sector during a certain time interval.

4. Assuming that replacement demand is not greatly influenced by economic fluctuations. 
$R_{3}=\frac{T D}{V}=\frac{\max (\Delta E, 0)+R D}{V}$

where:

$\boldsymbol{R}_{3} \quad$ = ratio total demand for newcomers/vacancies;

$T D=$ total demand for newcomers.

The ratio denotes the proportion of the total number of vacancies that is on balance open for newcomers. We assume that, because of the pro-cyclical fluctuations in job-to-job mobility described above, in an economic upswing the ratio $R_{3}$ will be small, whereas in an economic downswing $R_{3}$ will be high. Furthermore, in a period of economic growth the internal or external labour queues will be relatively small, which means that the level of undermeasurement in the vacancy statistics will be relatively low. Of course in a recession the opposite is the case. These two arguments suggest that fluctuations in the number of vacancies are not an adequate indicator of fluctuations in the total demand for newcomers on the labour market.

The final ratio is of crucial importance for the relevance of employment growth as an indicator of the total number of job openings for newcomers on the labour market. The ratio describes the relative importance of the two elements of expansion demand and replacement demand in the total demand for newcomers. This index is presented in equation (8):

$R_{4}=\frac{\max (\Delta E, 0)}{T D}=\frac{\max (\Delta E, 0)}{\max (\Delta E, 0)+R D}$

where:

$\boldsymbol{R}_{4} \quad=$ ratio employment growth/total demand.

As has been stated before, if employment levels are decreasing the total demand for newcomers equals replacement demand, and thus $\boldsymbol{R}_{\mathbf{4}}=0$. If employment is increasing, the ratio will be greater than zero. The ratio is important because, as has been stated before, in occupational and vocational counselling, the labour market prospects for newcomers on the labour market are often related only to expansion demand. Both policy-makers and occupational counsellors often focus particularly on growing segments of the labour market. We argue that demand related to departures from the workforce is also a very important component of the employment prospects for newcomers. This means that policy-makers and vocational counsellors should not focus only on employment levels, while ratio $R_{3}$ shows that the total number of vacancies is also not the most adequate measure of the employment prospect of newcomers. The central focus should be on the total demand for newcomers, neglecting intersectoral job-to-job mobility and including replacement demand. 


\section{FLUCTUATIONS IN VACANCIES AND EMPLOYMENT GROWTH}

In this section, changes in the number of vacancies will be described in relation to the growth of the working population from 1980 until 1990. The first half of the $1980 \mathrm{~s}$ is generally characterized as a recession period, followed by an economic upswing in the second half of the decade. By comparing employment growth rates $(\Delta E)$ and vacancy rates $\left(R_{1}\right)$, the extent to which these two rates reflect the recession and economic upswing periods can be analyzed. The analyses will refer to seven economic sectors, which probably enables us to say which sectors are most heavily affected by business cycle fluctuations.

The vacancy data used in this section refers to the vacancy surveys of the CBS. These annual surveys report on the number of vacancies by economic sector, occupational class and level of education, and indicate the bottlenecks in filling vacancies (Klaver and Sprangers, 1990). The survey is held among 20,000 enterprises. The survey does not include the public sector and temporary employment agencies. ${ }^{5}$ During the 1980 s the set-up of the vacancy survey was slightly changed, so that the surveys refer to different months: October (1980-1983), September (1984), January (1986-1988) and March (1989-1990). ${ }^{6}$ The sample represents about $10 \%$ of the population on average. The data on the working population used in this section is based on the National Accounts (Nationale Rekeningen) of the CBS.

Table 1 shows the employment growth and vacancy rate by economic sector during the eighties. An obvious decrease in the working population and few vacancies characterize the first few years of the decade (1980-1984), while a marked increase in both employment and the number of vacancies reflects the economic upswing in the second part of the decade. Unfortunately, because of data problems, employment mutation and vacancy rates in the second part of the eighties refer to periods that do not completely match. Nevertheless, as might be expected, both the employment and vacancy rates are considerably lower during the recession period, compared to the upswing period.

The general picture of an economic downward trend in the period 1980-1984 and an upward trend in 1985-1990 can be differentiated by economic sector. Employment growth rates show that the impact of economic conditions is most extreme in the construction sector. This sector faced a significant decline in the working population of approximately $7 \%$ per year during the recession period, in contrast to a $2 \%$ increase during the economic upswing. The vacancy rate also shows the strong cyclical sensitivity of this sector. The changes in the other manufacturing sectors are less marked. The utilities sector is the only sector for which the employment growth rate shows a counter-cyclical pattern, although in general this sector also changes quite smoothly.

5. In 1988 the categories not included in the survey represented about $22 \%$ of all jobs (Klaver and Sprangers, 1990). From 1993 the CBS intends to include all economic sectors in the vacancy survey.

6. This means the vacancy survey was not held in 1985 . 
Table 1. Average yearly employment mutation rates $(\dot{E})$ and vacancy rates $\left(R_{1}\right)$ by economic sector, $1980-1990$

\begin{tabular}{|c|c|c|c|c|}
\hline economic sector & $\begin{array}{c}\dot{E} \\
1980-^{\prime} 84\end{array}$ & $\begin{array}{c}R_{1} \\
1980-^{\prime} 84\end{array}$ & $\begin{array}{c}\dot{E} \\
1985-^{\prime} 89\end{array}$ & $\begin{array}{c}R_{1} \\
1986-' 90\end{array}$ \\
\hline agriculture & 0.003 & 0.004 & 0.024 & 0.038 \\
\hline manufacturing & -0.028 & 0.009 & 0.015 & 0.022 \\
\hline utilities & 0.005 & 0.005 & 0 & 0.015 \\
\hline construction & -0.069 & 0.007 & 0.022 & 0.030 \\
\hline trade, hotels and & & & & \\
\hline $\begin{array}{l}\text { restaurants, repair } \\
\text { transport, storage and }\end{array}$ & -0.015 & 0.007 & 0.030 & 0.023 \\
\hline communication & -0.001 & 0.003 & 0.023 & 0.011 \\
\hline other services & 0.011 & 0.014 & 0.022 & 0.025 \\
\hline total & -0.015 & 0.009 & 0.022 & 0.023 \\
\hline
\end{tabular}

The agricultural sector faced steady employment during the first half of the eighties, while in the second half employment in this sector rose by more than $2 \%$ per year on average. There was also a significant increase in the vacancy rate for the second part of the 1980s. From this we might conclude that the agricultural sector is also heavily affected by the economic situation. However, in this sector employment did not, on balance, decrease during the recession years. Finally, the service sectors show on average only a small loss of employment, or even a slight increase, during the recession and a higher employment growth rate in the upswing period. The vacancy rates for these economic sectors are also substantially higher for the upswing years than for the recession period.

We can conclude that in most cases, the differences between the vacancy rates during the recession and upswing periods are smaller than the differences between the employment growth figures for these two periods. Except for the utilities sector, which shows a countercyclical employment pattern, the absolute difference in the employment mutation figures is greater than the absolute difference in the vacancy rates for all economic sectors. The relative differences ${ }^{7}$ also show employment mutation figures following economic trends more closely than the vacancy rates.

7. Computed as the square of the differences between the value of the indicator for the two periods, divided by the mean of the squares of the indicator values in the recession period and the upswing period. 


\section{VACANCIES, EMPLOYMENT GROWTH, AND REPLACEMENT DEMAND}

From the previous section, vacancies would seem to be an adequate indicator of the labour market situation, as the ratio of vacancies to employment appears relatively low during recession, and relatively high during an economic upswing with a tight labour market. However, as stated in section 2, the total number of vacancies consists of three elements: employment growth, replacement demand, and job-to-job mobility. Only the first two elements are important for newcomers. Employment growth and replacement demand can on balance lead to job openings ${ }^{8}$ for newcomers. Therefore it is doubtful whether either the vacancy figures or the employment mutation data are a good indicator of the demand for newcomers and the fluctuations in this demand. In this section the relevance of the number of vacancies in assessing the labour market opportunities of newcomers is analyzed. We will distinguish eight economic sectors. Unfortunately, due to a lack of the relevant flow data, we can only refer to the period 1989-1990. Therefore we are not able to give a complete view of the 1980s. For occupational classes and levels of education no vacancy flow data is available at all.

This section focuses first on the relative importance of employment growth for the total number of vacancies $\left(R_{2}\right)$. Secondly, the portion of the total number of vacancies that is open for newcomers $\left(R_{3}\right)$, (i.e., the portion that refers to expansion demand and replacement demand for newcomers) will be calculated. Thirdly, the two elements of the total demand for newcomers will be considered $\left(R_{4}\right)$. The relative importance of employment growth and replacement demand is expected to differ in different economic sectors and to be influenced by the economic situation. This ratio will also be derived for occupational classes and levels of education.

The vacancy data used in this section are, in part, derived from the same vacancy surveys as were used in section 3. Data is also derived from the quarterly vacancy survey of the CBS. This quarterly survey has been held since 1988, with the aim of rapidly gathering information on vacancies. The quarterly survey provides not only stock data, but also flow data on the number of vacancies created and filled.

The data on the working population used in this section comes from the Labour Force Count (ArbeidsKrachtenTelling, Dutch abbreviation, AKT) for the first half of the eighties, and from the Labour Force Survey (Enquête BeroepBevolking, Dutch abbreviation EBB) for the second half. Both surveys were conducted by the CBS. Since 1987 the annual EBB survey has succeeded the AKT, which used to be held biannually until 1985. The sample fraction of the AKT is about $3-5 \%$ of the population living in the Netherlands. The sample fraction of the EBB is significantly smaller, $2 \%$ in 1988 and 1989 and $1 \%$ in 1990. The unavoidable use of data from two different surveys for our analysis implies some inconsistencies in the data.

8. Silvestri and Lukasiewicz (1991) label the ratio of total job openings to the employment level as the 'opportunity ratio'. 
We will begin by considering the relative importance of employment growth for the total number of vacancies. The analysis assumes that expansion demand is a limited part of the total demand. This is true especially for the economic sectors that are most heavily influenced by business cycle fluctuations. Table 2 shows the relation between net employment growth and vacancy flows by economic sector. ${ }^{9}$ It appears that net employment growth accounts for only a limited part of the vacancies. Moreover, the table shows that there are quite substantial differences between the various economic sectors. Unfortunately, there is no vacancy flow data available for the whole decade. Therefore we are not able to compare the relevency of employment growth for the total vacancy flows during a recession period and an upswing period.

The agricultural, construction and utilities, mining and quarrying sectors had particularly low ratios, indicating a relatively small share of total vacancies due to expansion demand. The manufacturing sector however, shows a relatively high ratio on average. The services sectors, which are little influenced by the economic situation according to the vacancy rates and employment, show relatively higher ratios from 0.16 to 0.34 on average, indicating a relatively higher share of total vacancies due to employment growth than the agricultural, construction and manufacturing sectors.

Table 2. Share of net employment growth in the total number of vacancy flows $\left(\boldsymbol{R}_{\mathbf{2}}\right)$ by economic sector, 1989-1990

Now it is interesting to consider the portion of the total vacancy flow that reflect job openings for newcomers, defined as the sum of employment growth and replacement demand. Table 3 shows the ratio of the total demand for newcomers to total vacancies, for the period 1989 to

9. This section employs data from surveys other than those used in section 3 , where 'mining and quarrying' is included in 'manufacturing' and the 'banking, insurance, and business services' sector is a part of the 'other services' sector. 
1990. As stated before, we have no data for comparing this ratio for the whole of the 1980 s, so that we can not analyse the effect of the business cycle on the relevance of the number of vacancies for the position of newcomers on the labour market.

The table shows that in the various sectors about $20 \%$ to $50 \%$ of the total number of vacancies can be characterized as job openings for newcomers, due to employment growth and replacement demand. The lowest ratio, indicating relatively few job openings for newcomers and high job mobility, is found in the construction sector. Obviously this extensive job mobility is due to the relatively short-term labour contracts used in the building sector and the seasonal character of the work. Moreover, as we have seen in section 3, the construction sector is heavily influenced by business cycle fluctuations, which could imply that the job mobility consists in part of transitions from employment to unemployment and vice versa.

Table 3. Share of job openings for newcomers on the labour market in the total number of vacancies $\left(R_{3}\right)$ by economic sector, 1989-1990

agriculture

manufacturing

construction

utilities, mining and quarrying

trade, hotels and restaurants, repair transport, storage and communication banking, insurance, and business services other services

total

\subsection{3}

0.48

0.20

1.02

0.38

0.49

0.45

0.42

0.42

Economic sectors with a relatively high number of vacancies for newcomers are: transport, storage and communication, and manufacturing. This means that these economic sectors have less intra-sectoral mobility. In more general terms, we can conclude that in relation to the number of vacancies, total demand for newcomers is greatest in the service sectors, while the agricultural and manufacturing sectors have a smaller number of job openings on average. In terms of job mobility, this means that job mobility is relatively higher for the agricultural and manufacturing sectors than the service sectors.

It is striking that the sector utilities, mining and quarrying has a ratio with a value greater than 1 , which is theoretically impossible. There are three possible causes for this phenomenon. First, due to the relatively small number of workers in this sector and the use of crudely rounded vacancy data, the indicator value might by quite inaccurate. Second, as already argued in section 2, the real number of vacancies can be under-reported in the vacancy statistics. For 
example, vacancies that are immediately filled by persons from a pool of internal or external applicants will probably not be reported in the surveys. Third, the periods for which employment growth and replacement demand on the one hand and vacancies on the other hand are measured do not exactly correspond, causing an inaccuracy.

Replacement demand would be expected to have been a relatively stable component of the total demand for newcomers during the 1980s, as demographical conditions were relatively constant and the institutional changes (early retirement schemes and increasing participation of women) to some extent counterbalanced each other. Calculations of replacement demand by means of cohort-change ratios (see equation (4)) indicate that replacement demand was indeed relatively stable during the eighties, although the relative replacement demand differs by economic sector. For the whole labour market replacement demand is approximately $3.5 \%$ per year. The agricultural sector, which is heavily affected by the business cycle and has a relatively small expansion demand, shows a relatively high replacement demand, probably due to the relatively high average age of the workers, implying a high number of retirements.

It is obvious that the economic situation influences the structure of the total demand for newcomers to the labour market. When employment stagnates or decreases, the demand for newcomers will only refer to replacement demand. However, when employment grows, the total demand for newcomers will equal the sum of expansion demand and replacement demand. The ratios in table 4 indicate the relative importance of the two elements of total demand, expansion demand and replacement demand for each economic sector.

Table 4. Share of net employment growth in the total number of job openings for newcomers $\left(\boldsymbol{R}_{\mathbf{4}}\right)$ by economic sector, 1981-1990

\begin{tabular}{|c|c|c|c|}
\hline economic sector & $81-' 85$ & 1985-'88 & 1988-'90 \\
\hline agriculture & 0 & 0.45 & 0.22 \\
\hline manufacturing & 0 & 0.57 & 0.67 \\
\hline construction & 0 & 0.20 & 0.43 \\
\hline utilities, mining and quarrying & 0 & 0.33 & 0 \\
\hline \multicolumn{4}{|l|}{ trade, hotels and } \\
\hline restaurants, repair & 0 & 0.74 & 0.62 \\
\hline $\begin{array}{l}\text { transport, storage and communication } \\
\text { banking, insurance, }\end{array}$ & 0.03 & 0.56 & 0.53 \\
\hline and business services & 0.60 & 0.85 & 0.75 \\
\hline other services & 0.50 & 0.87 & 0.38 \\
\hline total & 0.07 & 0.72 & 0.57 \\
\hline
\end{tabular}

Table 4 shows that business cycle fluctuations strongly affect the structure of the total number of job openings for newcomers. During the recession period 1981-1985 the total demand for 
newcomers would seem to consist mainly of replacement demand, as the $\boldsymbol{R}_{\mathbf{4}}$ ratios are very low, due to the stagnation of employment. Even in the recession period, the business services and other services sectors had expansion demand of $60 \%$ and $50 \%$ of the total demand for newcomers, respectively. It has to be noted that this employment growth has a 'double' effect on the indicator: because employment is growing in these sectors, relatively many young people will enter these economic sectors, so replacement demand will be relatively low. ${ }^{10}$ As mentioned before, the service sectors are hardly influenced by the business cycle.

The period 1985-1988 is characterized by a strong employment growth in almost all economic sectors, ${ }^{11}$ except the agricultural and construction sectors. In this upswing period, expansion demand generally accounts for a large part of the total job openings for newcomers, although replacement demand accounts for about $25 \%$ of the total number of job openings. However in the manufacturing sectors the share of replacement demand in the total demand for newcomers on the labour market is $40 \%$ to $80 \%$. In the agricultural sector $45 \%$ of the total job openings are caused by replacement demand.

During the last two years of the decade, replacement demand again accounts for a relatively large share of the total number of job openings for newcomers in the agricultural and utilities, mining and quarrying sectors, with proportions of $78 \%$ and $100 \%$, respectively. In these economic sectors expansion demand seems to be relatively unimportant for newcomers on the labour market. In contrast, expansion demand is more important for the service sectors, excluded 'other services', and the manufacturing sectors. Table 4 also shows that replacement demand generally has a stabilising effect on the total number of job openings for newcomers over the business cycle, which makes employment growth an inadequate indicator of the fluctuations in the total number of job openings.

The $R_{4}$ ratio can also be calculated for occupational classes. ${ }^{12}$ The ratios were generally low during the first half of the eighties, high during 1985-1988, and high during 1988-1990, but not as high as in the previous period. This is in accordance with the trends we have seen for economic sectors in table 4 . However the ratios for the various occupational classes are - in total - smaller than the economic sector ratios. It is most probable that this difference is due to differences in the level of aggregation, which of course affects the measurement of intercategory mobility.

The occupational classes for which expansion demand accounts for the largest share in the

10. The net effect of the quite extensive inter-sectoral job search behaviour of young people will probably be small, due to compensating flows.

11. The data used for this period is probably not completely consistent, as we compared 1985 AKT data with 1988 EBB data.

12. For a description of the occupational classes distinguished, see Van de Loo, Dekker, and De Grip (1992). 
total demand for newcomers are shown in table 5. The table shows that employment growth is relatively important for newcomers on the labour market for high skilled automation specialists, managers, and other - tertiary educated - specialized professions. For these 'high growth' occupational classes the share of replacement demand in the total number of vacancies for newcomers is limited. Moreover, it is striking that four of the ten occupational classes with the highest relative expansion demand for newcomers are commercial and administrative occupations. It is important to notice that as high growth occupations attract many young people, replacement demand will probably also be low in the near future. This makes the job openings for newcomers in these occupations heavily dependent on the future expansion demand, which means that if employment growth in an occupational class stagnates, the demand for newcomers will probably collapse.

The lowest ratios apply to transport professions. For the occupational classes sailors, deckhands, and engine-room workers, intermediate marine and inland waterways occupations and freight handlers, packers, and packaging workers, vacancies for newcomers were exclusively due to replacement demand during 1981-1985 and 1989-1990, while during the other years expansion demand played only a limited role.

Table 5. Share of employment growth in the total number of job openings for newcomers $\left(\boldsymbol{R}_{\mathbf{4}}\right)$ by occupational class (10 highest ratios), 1981-1990

\begin{tabular}{|c|c|c|c|}
\hline occupational class & $81-85$ & $1985-' 88$ & $1988-^{\prime} 9$ \\
\hline $\begin{array}{l}\text { system analysts, programmers, } \\
\text { system supervisors }\end{array}$ & 0.90 & 1.00 & 0.76 \\
\hline administrative supervisors & 0.86 & 0.93 & 0.96 \\
\hline $\begin{array}{l}\text { directors, managers, foremen, } \\
\text { and supervisors manufacturing }\end{array}$ & 0.78 & 0.82 & 0.79 \\
\hline senior managers & 0.73 & 0.81 & 0.76 \\
\hline $\begin{array}{l}\text { registered nurses, district nurses, } \\
\text { and midwives }\end{array}$ & 0.73 & 0.93 & 0.61 \\
\hline legal professionals & 0.78 & 0.87 & 0.44 \\
\hline $\begin{array}{l}\text { geriatric help, kindergarten staff, } \\
\text { nannies etc. }\end{array}$ & 0.55 & 0.80 & 0.66 \\
\hline $\begin{array}{l}\text { visual and performing artists } \\
\text { scientific researchers and }\end{array}$ & 0.27 & 0.95 & 0.78 \\
\hline $\begin{array}{l}\text { engineering trades } \\
\text { school principals and }\end{array}$ & 0.31 & 0.96 & 0.70 \\
\hline other higher educational professions & 0.54 & 0.87 & 0.53 \\
\hline total & 0.06 & 0.68 & 0.46 \\
\hline
\end{tabular}

In the first half of the 1980 s several occupational classes had a relatively high expansion demand, despite the small contribution of expansion demand to the total demand for newcomers for the entire labour market in this period. Some examples are intermediate mechanical engineers, marine engineers, etc., architects, civil engineers, city planners, etc., 
system analysts, programmers, system supervisors, and administrative supervisors. For the latter two occupational classes the total demand for newcomers also consisted mainly of expansion demand in the period 1985-1988. For the system analysts, programmers, and system supervisors, total demand consisted entirely of employment growth. In 1988-1990, however, the relative importance of replacement demand was increasing, which could indicate that the enormous growth of this occupational class during the first years of the 1980s was decreasing.

Table 6 shows the share of expansion demand in the total demand for newcomers on the labour market by skill level. ${ }^{13}$ The ratios seem to correspond with our findings above for economic sectors and occupational classes. We can see that the $\boldsymbol{R}_{\mathbf{4}}$ ratios are - in total - greater than the ratios for economic sectors and occupational classes. This is because the replacement demand by educational level does not include a mobility component $\left(R D_{2}\right.$ in equation (3)).

Table 6. Share of employment growth in the total number of job openings for newcomers $\left(\boldsymbol{R}_{\mathbf{4}}\right)$ by educational level, 1981-1990

primary education

lower general secondary education and lower vocational education

higher general secondary education and intermediate vocational education

higher vocational education

academic education

total
0

0

0.70

0.89

0.90

0.13
0

0.53

0.75

0.80

0.88

0.68

In the first half of the decade, the share of employment growth in the total demand for newcomers increases with the educational level, from $0 \%$ for primary and lower general secondary education and lower vocational education to $90 \%$ for academic education. Moreover, it is striking that the three upper skill levels show very high ratios, indicating high employment growth in relation to the total demand for newcomers. Strikingly, for most skill levels we see hardly any differences for the second half of the decade. For unskilled workers (primary education only) the ratio remains zero in this upswing period and for the intermediate and more highly skilled workers the ratios remain at the relatively high levels of the first half of the 1980s. The business cycle fluctuation is reflected only in the increasing ratio for lower general secondary education and lower vocational education, where the share of expansion demand increases from zero to approximately $50 \%$ of the total number of vacancies for newcomers in this period.

13. Unfortunately, we cannot split up the period 1986-1990 here, as we did for the economic sectors and the occupational classes. 
The table shows that for unskilled workers (primary education only) there has not been any employment growth in any part of the 1980s, regardless of the tendency of the total market. The demand for unskilled newcomers is therefore totally dependent on the replacement demand. For highly skilled workers, in particular, the reverse holds. The total number of job openings for newcomers in the 1980s was determined almost entirely by employment growth. As relatively many young people have entered the labour market for this skill category, the labour market situation for highly skilled workers will also be heavily dependent on expansion demand, with hardly any stabilizing effect on the demand for newcomers because of replacement demand. 


\section{CONCLUSIONS}

As has been shown in this paper, the total number of vacancies is made up of three elements: (1) employment growth ('expansion demand'), (2) replacement demand, and (3) job-to-job mobility. Only the first two components are on balance important for the newcomers on the labour market. Therefore vacancy data and employment growth rates do not represent the opportunities for newcomers in an adequate way. In order to come to an exploratory empirical analysis have described several ratios that focus directly or indirectly on the relation between vacancy data, employment growth, and replacement demand. Most analyses in this paper refer to economic sectors. Due to a lack of flow data we unfortunately could not completely analyze the vacancy data by occupational class and educational level.

The vacancy rate is a very simple indicator of labour market tensions. However the employment growth figures can generally give us a more definite indication of the effects of economic fluctuations than the vacancy rates do. The agricultural and the construction sectors are most sensitive to economic fluctuations. The second ratio we have derived relates the net employment growth (by economic sector) to the total vacancy flows. In the period 1989-1990, on average $20 \%$ of all vacancies were due to net employment growth.

The third ratio we described indicates the share of job openings for newcomers in the total number of vacancies. This ratio is therefore of crucial importance for the central problem of this paper, the relevance of the vacancy data for the labour market opportunities for newcomers. On balance only $40 \%$ of the vacancies are open for new job seekers. So we may conclude that vacancy data is no adequate measure of newcomers' opportunities on the labour market.

Finally, we have examined the relative share of expansion demand and replacement demand in the total number of job openings. This ratio gives empirical evidence of the relevance of employment growth rates as an indicator of the total number of job openings for newcomers on the labour market. These analyses refer to economic sectors, occupational classes and educational levels. It appears that a substantial part of the total demand for newcomers is due to replacement demand. Especially in the recession period in the early 1980s, the total number of job openings for newcomers is almost entirely related to replacement demand. This means that both policy-makers and vocational counsellors should not focus only on the growing segments of the labour market, but also consider the more or less stabilising effect of replacement demand on the demand for newcomers.

For unskilled workers the total number of job openings for newcomers in the 1980s was entirely determined by replacement demand. However, for more highly skilled workers in general and those employed in high growth occupations in particular, the total demand for newcomers refers to a large extent to employment growth. This means that in the near future the job opportunities for these workers will continue to be determined mainly by employment growth, the stabilising effect of replacement demand on the total demand for newcomers being absent. 


\section{REFERENCES}

Allaart, P.C., W.C.M. Praat, and J.P.M. Vosse (1992), Trendrapport vraag naar arbeid 1992 (Trend Report, Demand for Labour 1992), OSA report no. 16, Den Haag.

Beekman, T., R. Dekker, A. De Grip, and H. Heijke (1991), An Explanation of the Educational Structure of Occupations, Labour, vol. 5, no. 3, pp. 151-163.

Budd, A,. P. Levine and P. Smith (1987), Long-term Unemployment and the Shifting UV Curve, European Economic Review, vol. 31, pp. 296-305.

De Grip, A., J.A.M. Heijke, and R.J.P. Dekker (1989), The Labour Market by Education and Occupation in 1992, ROA-R-1989/8E, Research Centre for Education and the Labour Market, Maastricht.

De Grip, A., and E.J.T.A. Willems (1992), De vervangingsvraag naar beroepsklasse tot 2000 (The Replacement Demand by Occupational Class till 2000), OSA working document W96, Den Haag.

Holt, C.C. (1970), Job Search, Phillips-Wage Relation and Union Influence: Theory and Evidence, in: Phelps, E.S. (ed.), Micro Foundations of Unemployment and Inflation Theory, London, pp. 53-123.

Klaver, T., and A.H. Sprangers (1990), De kwartaal vacature-enquête; methoden en uitkomsten ('Quarterly Vacancy Survey; Methods and Results'), Supplement bij de Sociaal-Economische Maandstatistiek, nr. 5, pp. 18-24.

Kuipers S.K., and F.H. Buddenberg (1978), Unemployment on Account of Market Imperfections in the Netherlands since the Second World War, De Economist, vol. 126, nr. 3, pp. 380-412.

Organisation for Economic Co-operation and Development (1992), Employment Outlook, OECD, Paris.

Schettkat, R. (1992), Mismatch in the West German Labour Market? Economic Restructuring and Unemployment in the 1980s, Labour, vol. 6, no. 1, pp. 121-139.

Schwan, R., and J. Soeters (1990), The Strategy of Vacancy Filling from Internal and External Labour Market Sources, Paper for the conference of the European Association of Labour Economists, September 1990, Lund.

Shryock, H.S., and J.S. Siegel (1980), The Methods and Materials of Demography, U.S. Bureau of the Census, U.S. Government Printing Office, Fourth Printing (rev.), Washington D.C.. 
Silvestri, G., and J. Lukasiewicz (1991), Outlook: 1990-2005: Occupational Employment Projections, Monthly Labor Review, November 1991, pp. 64-94.

Van Bastelaer, A., and J. Laan (1993), The Job Vacancy Survey in the Netherlands, paper presented at the workshop 'Measurement and Analysis of Vacancies: An International Comparison', 28th-29th January 1993, Maastricht.

Van de Loo, P.J.E., R.J.P. Dekker, and A. De Grip (1992), Arbeidsmarktsegmentatie als uitgangspunt voor een beroepenclassificatie ('Labour Market Segmentation as Starting Point for an Occupational Classification'), Tijdschrift voor Arbeidsvraagstukken, vol. 8, nr. 1, pp. 19-31.

Van der Bij, W. (1992), Vacaturebehandeling in cijfers; Eerste kwartaal 1992 (Vacancy Handling in Figures; First Quarter 1992), OAV working document 92-05, Arbeidsvoorzieningsorganisatie, Rijswijk.

Van der Velden, R.K.W., and E.J.T.A. Willems (1992), The Market Position of Occupations and Types of Education, Contribution to the Symposium 'Education and the Labour Market: From Research to Policy-Making', May 8th, Maastricht.

Van Ophem, J.C.M. (1989), Theoretical and Empirical Studies on Job Mobility, dissertation, Faculty of Economics and Econometrics, University of Amsterdam, Amsterdam.

Van Ours, J.C. (1987), Knelpunten in de vacaturevervulling (Bottlenecks in Filling Vacancies), Economisch Statistische Berichten, vol. 72, no. 3629, pp. 1012-1017.

Van Ours, J.C. (1989), Durations of Dutch Job Vacancies, De Economist, vol. 137, nr. 3, pp. 309-327.

Willems, E.J.T.A., and A. De Grip (1993), Forecasting Replacement Demand by Occupation and Education, International Journal of Forecasting, forthcoming. 